\title{
Vitamin D Deficiency in Children and Adolescents with Type 1 Diabetes
}

\author{
Ajda Mutlu1, Gül Yeşiltepe Mutlu2, Elif Özsu2, Filiz Mine Çizmecioğlu2, Şükrü Hatun2 \\ ${ }^{1}$ Kocaeli University, Medical Faculty, Department of Pediatrics, Kocaeli, Turkey \\ ${ }^{2}$ Kocaeli University, Medical Faculty, Department of Pediatrics, Division of Pediatric Endocrinology and Diabetes, Kocaeli, Turkey
}

\begin{abstract}
Objective: To investigate the frequency and effects of vitamin $D$ deficiency in children with type 1 diabetes (T1D) in a region which is known to have a high rate of vitamin $D$ deficiency among adolescents.

Methods: In this prospective cross-sectional study, 120 children and adolescents with T1D ( 55 girls and 65 boys) aged 3-20 years were evaluated. Serum 25-hydroxyvitamin D [25(OH)D], parathormone (PTH), and alkaline phosphatase (ALP) levels were measured. Hemoglobin A1c levels and daily insulin requirement were also evaluated. Classification of vitamin D status was made according to the American Academy of Pediatrics (AAP)/LWEPS's recommendations. The patients were divided into 2 groups according to their vitamin D status and also according to the season of the year in which $25(\mathrm{OH}) \mathrm{D}$ sampling was done.

Results: Serum $25(\mathrm{OH}) \mathrm{D}$ levels revealed vitamin $\mathrm{D}$ deficiency or insufficiency in $38 \%$ of the patients. Higher PTH levels were found in the patient group whose mean $25(\mathrm{OH}) \mathrm{D}$ level was $<20 \mathrm{ng} / \mathrm{mL}$ as compared to the group whose mean $25(0 \mathrm{H}) \mathrm{D}$ level was $>20 \mathrm{ng} / \mathrm{mL}(\mathrm{p}<0.05)$. Only $11 \%$ of patients had secondary hyperparathyroidism. The $25(\mathrm{OH}) \mathrm{D}$ levels of patients whose serum samples were taken in summer and spring months were significantly different $(p<0.05)$. There were no significant correlations between 25(OH)D level and daily insulin dose.

Conclusion: Although we could not show a significant association between vitamin $D$ deficiency and metabolic parameters, the frequency of vitamin D deficiency in T1D children is substantial. Vitamin D status should be assessed also in patients who do not have signs of rickets.

Key words: Vitamin D, Type 1 diabetes, children and adolescents
\end{abstract}

Conflict of interest: None declared

Received: 14.07.2011

Accepted: 01.10.2011

\section{Introduction}

There is a growing interest in the non-skeletal effects of vitamin $D$ in recent years (1). There are some reports suggesting that vitamin $D$ deficiency has a negative effect on insulin sensitivity and that it increases type 2 diabetes prevalence in adults $(2,3,4,5)$. Some studies establishing a relationship between vitamin $D$ and insulin sensitivity in children have also been published $(6,7)$. Recently, high rates of vitamin $D$ deficiency have been reported in children with type 1 diabetes (T1D) and it is emphasized that this situation may have a negative effect on bone health $(8,9,10,11,12,13)$. A positive effect of vitamin $\mathrm{D}$ administered in high doses $(4000$ IU/day) on metabolic control has also been reported (14). However, prevalence of vitamin D deficiency in children with T1D and its effects on metabolic control, insulin requirement and lipid levels have not yet been fully clarified.

In this study, we aimed to investigate the frequency and effects of vitamin $D$ deficiency in children with T1D. A high rate of vitamin $\mathrm{D}$ deficiency is encountered among adolescents in our region (15).

\section{Materials and Methods}

The study group consisted of one hundred twenty patients with T1D who were being followed in our pediatric endocrinology outpatient clinic. The mean age of patients was $12.7 \pm 3.8$ years (range: $2.9-20.1$ years). Fifty four percent of the patients $(n=65)$ were boys and $46 \%(n=55)$ were girls.

Address for Correspondence

Filiz Mine Çizmecioğlu MD, Kocaeli University, Medical Faculty, Department of Pediatrics, Division of Pediatric Endocrinology and Diabetes, Kocaeli, Turkey Phone: +90 2623037228 Fax: +90 2623037003 E-mail: filizcizmeci@gmail.com

() Journal of Clinical Research in Pediatric Endocrinology, Published by Galenos Publishing. 
None of the patients were taking a vitamin D supplement. Serum 25-hydroxyvitamin D [25(OH)D], parathormone $(\mathrm{PTH})$, and alkaline phosphatase (ALP) levels were measured. Hemoglobin A1c (HbA1c) levels (mean of the measurements of the preceding year) and daily insulin requirement of the patients were evaluated. The season in which $25(\mathrm{OH}) \mathrm{D}$ samples were taken was also recorded.

The participants were divided into two groups according to their pubertal stage. Group 1 consisted of prepubertal children $(n=29)$ and group 2 - of children who had reached puberty $(n=91)$.

Because vitamin D status is associated with sunlight exposure, a variable which changes with the season of the year, the participants were categorized according to $25(\mathrm{OH}) \mathrm{D}$ sampling season: winter (December 22-March 21), spring (March 22-June 21), summer (June 22-September 21), and fall (September 22-December 21).

Vitamin D status was classified according to the American Academy of Pediatrics (AAP)/LWEPS's recommendations on cut-off levels for states of vitamin D. A 25(OH)D level of $<5$ $\mathrm{ng} / \mathrm{mL}(<12.5 \mathrm{nmol} / \mathrm{L})$ was considered as severe deficiency, a level between 5 and $15 \mathrm{ng} / \mathrm{mL}(12.5-37.5 \mathrm{nmol} / \mathrm{L})$ as deficiency, a level of $15-20 \mathrm{ng} / \mathrm{mL}(37.5-50 \mathrm{nmol} / \mathrm{L})$ as insufficiency, and a level of $20-100 \mathrm{ng} / \mathrm{mL}$ (50-250 nmol/L) as normal (sufficient) (16). Our patients were also divided into 2 groups according to their vitamin D status. Those with $25(\mathrm{OH})$ D levels $<20 \mathrm{ng} / \mathrm{mL}$ were grouped as vitamin $D$ insufficient and deficient, and those with 25(OH)D levels $>20$ $\mathrm{ng} / \mathrm{mL}$ as normal with regard to vitamin $\mathrm{D}$ status.

Serum 25(OH)D level was measured by ELISA reader and the microELISA method. Serum level of ALP was measured using a Beckman CX-9 autoanalyzer. Serum PTH was measured by an original assay using Roche Diagnostics E-170 Modular Analytics immunoanalyzer equipment. The manufacturer's normal range for PTH was $15-65 \mathrm{pg} / \mathrm{mL}$ and intra- and interassay CVs were 2.8 and $3.4 \%$, respectively. Secondary hyperparathyroidism was defined as a PTH level greater than $65 \mathrm{pg} / \mathrm{mL}$. HbA1c levels were measured by high-performance liquid chromatography (HPLC).

\begin{tabular}{lc}
\hline \multicolumn{2}{l}{ Table 1. Demographic and biochemical features of patients } \\
\hline Age & $12.7 \pm 3.8$ years $(2.9-20.1)$ \\
\hline Gender & Girls: $46 \%$ ( $\mathrm{n}=55)$ \\
& Boys: $54 \%(\mathrm{n}=65)$ \\
Duration of T1D & $3.2 \pm 2.3$ years $(0.7-12.8)$ \\
Daily insulin requirement (U/kg/d) & $0.87 \pm 0.24(0.16-1.5)$ \\
HbA1c (\%) & $8.2 \pm 1.4(5.5-12.9)$ \\
25(OH)D & $25.6 \pm 16.2 \mathrm{ng} / \mathrm{mL}(4.6-101)$ \\
ALP & $237.6 \pm 116.9 \mathrm{u} / \mathrm{L}(39-746)$ \\
PTH & $38.9 \pm 18.3 \mathrm{pg} / \mathrm{mL}(12.8-97.7)$ \\
\hline T1D: type 1 diabetes, HbA1c: hemoglobin A1c, $25(\mathrm{OH}) \mathrm{D}: 25$-hydroxyvitamin D, \\
ALP: alkaline phosphatase, PTH: parathormone
\end{tabular}

The statistical analyses were performed with SPSS 13.0 software for Windows (SPSS Inc., Chicago, IL, USA). Mean values were compared using the Student's t-test and Analysis of Variance (ANOVA). Pearson's correlation analysis was used to reveal the relationships between $25(\mathrm{OH}) \mathrm{D}$ levels and daily insulin requirement of patients. The results were expressed as mean $\pm S D$. A p-value of less than 0.05 was considered statistically significant.

\section{Results}

The demographic and biochemical features of the patients are shown in Table 1. Serum 25(OH)D levels in $37.5 \%(n=45)$ of the patients revealed vitamin D deficiency or insufficiency. $0.8 \%(n=1)$ of patients had severe vitamin $D$ deficiency. $21.7 \%(n=26)$ had vitamin D deficiency, and $15 \%$ $(n=18)$ had vitamin $D$ insufficiency. The $25(\mathrm{OH}) \mathrm{D}$ status level was normal (sufficient) in $60 \%(n=72)$ of the patients. A small fraction of the patients, $2.5 \%(n=3)$, had vitamin $D$ excess.

No significant differences were found between the $25(\mathrm{OH}) \mathrm{D}$ levels of girls and boys. The mean $25(\mathrm{OH}) \mathrm{D}$ level of the girls was $25.5 \pm 21.1 \mathrm{ng} / \mathrm{mL}$ (range: $4.6-101$ ) and that of the boys was $25.8 \pm 10.7 \mathrm{ng} / \mathrm{mL}$ (range: 10.9-56.4), (p>0.05). Only five girls $(9 \%)$ wore concealing clothes for religious reasons. The serum 25(OH)D levels of these five girls were 9, 13.7, 11.6, 101, and $16.1 \mathrm{ng} / \mathrm{mL}$; the mean 25(OH)D level was $30.3 \pm 39.5 \mathrm{ng} / \mathrm{mL}$ (median=13.7 ng/mL).

Table 2. The comparison of prepubertal and pubertal participants

\begin{tabular}{|c|c|c|c|}
\hline & $\begin{array}{l}\text { Prepubertal } \\
n=29(24 \%)\end{array}$ & $\begin{array}{c}\text { Pubertal } \\
n=91(76 \%)\end{array}$ & $p$ value \\
\hline \multicolumn{4}{|l|}{ Age (years) } \\
\hline Mean $\pm S D$ & $7.6 \pm 2.6$ & $14.3 \pm 2.5$ & \multirow{2}{*}{$\mathrm{p}<0.01$} \\
\hline Range & $2.9-11.8$ & $8.8-20.1$ & \\
\hline \multicolumn{4}{|l|}{ Sex } \\
\hline Male & $21(72.4 \%)$ & $44(48.4 \%)$ & \multirow{2}{*}{$\mathrm{p}<0.05$} \\
\hline Female & $8(27.6 \%)$ & 47 (51.6\%) & \\
\hline \multicolumn{4}{|l|}{ Duration of T1D (years) } \\
\hline Mean & $2.5 \pm 1.3$ & $3.9 \pm 2.5$ & \multirow{2}{*}{$\mathrm{p}<0.01$} \\
\hline Range & $0-6.3$ & $0-12.9$ & \\
\hline \multicolumn{4}{|l|}{ HbA1c (\%) } \\
\hline Mean & $8 \pm 1.2$ & $8.3 \pm 1.5$ & \multirow{2}{*}{ NS } \\
\hline Range & $6.1-12$ & $5.5-12.9$ & \\
\hline \multicolumn{4}{|l|}{$25(\mathrm{OH}) \mathrm{D}(\mathrm{ng} / \mathrm{mL})$} \\
\hline Mean & $26.4 \pm 11.9$ & $25.4 \pm 17.4$ & \multirow{2}{*}{ NS } \\
\hline Range & $10.9-56.4$ & $5.5-12.9$ & \\
\hline $\begin{array}{l}\text { Frequency of vitamin } \\
\text { D deficiency/insufficiency }\end{array}$ & $9(31 \%)$ & $36(39.6 \%)$ & NS \\
\hline
\end{tabular}


Twenty four percent $(n=29)$ of the study group was prepubertal and $76 \%(n=91)$ was pubertal. The mean $25(\mathrm{OH}) \mathrm{D}$ levels in the prepubertal and pubertal groups were similar $(26.4 \pm 11.9$ and $25.4 \pm 17.4 \mathrm{ng} / \mathrm{mL}$, respectively, $p>0.05)$. The characteristics of the prepubertal and pubertal participants are given in Table 2. There was no difference between prepubertal and pubertal patients in terms of metabolic control and vitamin D status.

In the 45 patients $(37.5 \%)$ whose mean $25(\mathrm{OH})$ D level was lower than $20 \mathrm{ng} / \mathrm{mL}$, the mean PTH level was $44.6 \pm 24 \mathrm{pg} / \mathrm{mL}$ and the mean ALP level was $237 \pm 137.6 \mathrm{U} / \mathrm{L}$. In the 75 patients $(62.5 \%)$ whose mean $25(\mathrm{OH}) \mathrm{D}$ level was higher than $20 \mathrm{ng} / \mathrm{mL}$, the mean PTH level was $35.5 \pm 12.8 \mathrm{pg} / \mathrm{mL}$ and the mean ALP level was $237 \pm 103.4 \mathrm{U} / \mathrm{L}$. PTH levels in the group whose mean $25(\mathrm{OH}) \mathrm{D}$ level was lower than $20 \mathrm{ng} / \mathrm{mL}$ were significantly higher than in the other subgroup whose mean $25(\mathrm{OH}) \mathrm{D}$ level was greater than $20 \mathrm{ng} / \mathrm{mL}(\mathrm{p}<0.05)$. Only 13 patients $(10.8 \%)$ had secondary hyperparathyroidism. There was no significant difference in terms of daily insulin requirement and $\mathrm{HbA} 1 \mathrm{c} \%$ in the two groups (Table 3). Also, there was no significant correlation between $25(\mathrm{OH}) \mathrm{D}$ level and daily insulin dose $(r=-0.07, p>0.05)$.

The rates of $25(\mathrm{OH}) \mathrm{D}$ samples taken at different time of the year were as follows: $42 \%$ in the summer, $23 \%$ in the winter, $21 \%$ in the spring, and $14 \%$ in the fall. The mean $25(\mathrm{OH}) \mathrm{D}$ levels of patients according to the seasons were respectively: $30.4 \pm 10.4 \mathrm{ng} / \mathrm{mL}, 24.8 \pm 26.7 \mathrm{ng} / \mathrm{mL}, 17.5 \pm 7.3$ $\mathrm{ng} / \mathrm{mL}$ and $25 \pm 11.2 \mathrm{ng} / \mathrm{mL}$. One-way ANOVA showed significant differences between the means $(p<0.05)$. The significant result was caused by the difference in $25(\mathrm{OH}) \mathrm{D}$ levels of patients whose serum samples were taken in the summer and those of patients whose samples were taken in the spring. Mean serum PTH, ALP and 25(OH)D levels of patients according to season are shown in Table 4.

\section{Discussion}

In recent years, studies suggesting that vitamin $D$ deficiency correlates with the severity and frequency of T1D and that vitamin $D$ supplementation reduces the risk of developing T1D have been reported $(17,18)$. On the other hand, although the number of studies on frequency of vitamin $\mathrm{D}$ deficiency in children and adolescents with T1D is limited, this frequency was found to be highly variable and may be as low as $15 \%$ or as high as $90.6 \%(10,11,13,19,20)$ (Table 5). Studies indicating that T1D patients have lower vitamin D levels than control groups have also been reported $(8,9,10,12)$.

In this study, we found the prevalence of vitamin D deficiency in children with T1D as $21.7 \%$ and our results were similar to those reported by Svoren et al (11) and Tunc et al (19). The reasons for the different frequencies given from different countries for vitamin $D$ deficiency could be related to the variability of vitamin D deficiency definition (Table 5). Geographical environment and latitude may have influenced this variability (e.g., the latitudes of countries/ cities listed in Table 5 were: Boston: 42 $19^{\prime}$ North,

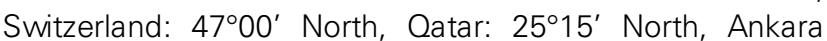
$39^{\circ} 55^{\prime}$ and Kocaeli: $40^{\circ} 45^{\prime}$ North).

Despite the high frequency of vitamin D deficiency (65\%) in healthy adolescents in our region, we found the frequency of vitamin $D$ deficiency in T1D children lower than that reported for healthy subjects (15). However, the limitation of this present study is the absence of an age- and gendermatched control group.

Although the mean PTH level of the vitamin D insufficient group was below the cut-off value for hyperparathyroidism, it was significantly higher than that of the vitamin $D$ sufficient group. We observed secondary hyperparathyroidism only in $10.8 \%$ of all patients whose vitamin D level was lower than $20 \mathrm{ng} / \mathrm{mL}$. Janner et al (20) had found the prevalence of secondary hyperparathyroidism low in vitamin $D$ deficient T1D patients as well. These findings indicate that all vitamin $D$ deficient T1D patients do not have secondary hyperparathyroidism. Similarly, in a study from our region, secondary hyperparathyroidism frequency was very low (3\%) among vitamin $D$ deficient/insufficient adolescent girls who were known to be otherwise healthy (15).

There are recent publications discussing the effects of vitamin D supplementation and even active vitamin D

\begin{tabular}{|c|c|c|c|}
\hline Vitamin D status & $\begin{array}{c}\text { Insufficient / deficient } \\
25(0 \mathrm{H}) \mathrm{D} \text { level }<20 \mathrm{ng} / \mathrm{mL} \\
\mathrm{n}=45(36.5 \%)\end{array}$ & $\begin{array}{c}\text { Sufficient } \\
\text { 25(OH)D level }>20 \mathrm{ng} / \mathrm{mL} \\
\mathrm{n}=72(60 \%)\end{array}$ & $p$ value \\
\hline $\operatorname{ALP}(\mathrm{U} / \mathrm{L})$ & $237 \pm 137.6$ & $237 \pm 103.4$ & NS \\
\hline PTH $(p g / m L)$ & $44.6 \pm 24$ & $35.5 \pm 12.8$ & $0.02^{*}$ \\
\hline HbA1c (\%) & $8.1 \pm 1.4$ & $8.3 \pm 1.5$ & NS \\
\hline Daily insulin requirement( $\mathrm{U} / \mathrm{kg} / \mathrm{d})$ & $0.86 \pm 0.22$ & $0.88 \pm 0.28$ & NS \\
\hline
\end{tabular}

${ }^{*}$ significant: $p<0.05$; NS: non-significant;

HbA1c: hemoglobin A1c, 25(OH)D: 25-hydroxyvitamin D, ALP: alkaline phosphatase, PTH: parathormone 
Table 4. Mean serum 25(OH)D, ALP and PTH levels of patients according to season

\begin{tabular}{|c|c|c|c|c|c|}
\hline & Spring $n=25(20.8 \%)$ & Summer $n=50(41.7 \%)$ & Fall $n=16(17.7 \%)$ & Winter $n=29(24.2 \%)$ & p value \\
\hline \multicolumn{6}{|l|}{ Age (years) } \\
\hline Mean \pm SD & $13.9 \pm 4.3$ & $12.6 \pm 3.7$ & $11.6 \pm 3.2$ & $12.5 \pm 3.8$ & \multirow{2}{*}{ NS } \\
\hline Range & $2.9-20.1$ & $2.9-19.3$ & $4.8-15.5$ & $5-18.9$ & \\
\hline \multicolumn{6}{|l|}{ Sex } \\
\hline Male & $13(52 \%)$ & $26(52 \%)$ & $10(62.5 \%)$ & $16(55.2 \%)$ & \multirow{2}{*}{ NS } \\
\hline Female & $12(48 \%)$ & $24(48 \%)$ & $6(37.5 \%)$ & $13(44.8 \%)$ & \\
\hline \multicolumn{6}{|c|}{ Duration of T1D (years) } \\
\hline Mean & $3.3 \pm 2$ & $3.8 \pm 2.6$ & $3 \pm 2.1$ & $3.5 \pm 2.3$ & \multirow{2}{*}{ NS } \\
\hline Range & $1.1-10.2$ & $0-12.9$ & $0-9.3$ & $1.2-11.5$ & \\
\hline \multicolumn{6}{|l|}{ HbA1c (\%) } \\
\hline Mean & $8.2 \pm 1.5$ & $8.3 \pm 1.7$ & $7.9 \pm 0.9$ & $8.2 \pm 1.2$ & \multirow{2}{*}{ NS } \\
\hline Range & $6.5-12$ & $5.5-12.9$ & $6.2-9.7$ & $6.1-11.5$ & \\
\hline \multicolumn{6}{|c|}{$25(0 \mathrm{H}) \mathrm{D}(\mathrm{ng} / \mathrm{mL})$} \\
\hline Mean & $17.5 \pm 7.3$ & $30.4 \pm 10.4$ & $25 \pm 11.2$ & $24.8 \pm 26.7$ & \multirow{2}{*}{$\mathrm{p}<0.05^{*}$} \\
\hline Range & $4.6-30$ & $11-56.1$ & $11.6-56.4$ & $6.1-11.5$ & \\
\hline \multicolumn{6}{|l|}{ PTH (pg/mL) } \\
\hline Mean & $51.6 \pm 23.3$ & $34.9 \pm 13.9$ & $36.3 \pm 14.8$ & $36.3 \pm 17.9$ & \multirow{2}{*}{$\mathrm{p}<0.05^{*}$} \\
\hline Range & $12.8-97.7$ & $17.6-84$ & $16.3-61.4$ & $13.9-92.3$ & \\
\hline
\end{tabular}

${ }^{*}$ One-way-ANOVA showed a significant difference because of the difference between spring and summer samples

$\mathrm{HbA1c}$ : hemoglobin A1C, 25(OH)D: 25-hydroxyvitamin D, ALP: alkaline phosphatase, PTH: parathormone

Table 5. Recent studies investigating vitamin D deficiency prevalence in T1D children

\begin{tabular}{lccc}
\hline & $\begin{array}{c}\text { Prevalence of vitamin } \\
\text { D deficiency in } \\
\text { T1D children }\end{array}$ & $\begin{array}{c}\text { Vitamin D } \\
\text { deficiency levels } \\
\text { accepted as cut-off } \\
\text { criteria }\end{array}$ & $\begin{array}{c}\text { Reference } \\
\text { no }\end{array}$ \\
\hline Svoren et al (11) & $15 \%$ & $\leq 20 \mathrm{ng} / \mathrm{mL}(50 \mathrm{nmol} / \mathrm{L})$ & $26^{*}$ \\
Janner et al (20) & $60.5 \%$ & $<20 \mathrm{ng} / \mathrm{mL}(50 \mathrm{nmol} / \mathrm{L})$ & $27^{*}$ \\
Bener et al (13) & $90.6 \%$ & $<30 \mathrm{ng} / \mathrm{mL}(75 \mathrm{nmol} / \mathrm{L})$ & $28^{*}$ \\
Greer et al (10) & $43 \%$ & $<20 \mathrm{ng} / \mathrm{mL}(50 \mathrm{nmol} / \mathrm{L})$ & $* *$ \\
Tunc et al (19) & $28 \%$ & $<20 \mathrm{ng} / \mathrm{mL}(50 \mathrm{nmol} / \mathrm{L})$ & $* *$ \\
$\begin{array}{l}\text { Our study } \\
\text { (Kocaeli,Turkey) }\end{array}$ & $21.7 \%$ & $<15 \mathrm{ng} / \mathrm{mL}(37.5 \mathrm{nmol} / \mathrm{L})$ & $21^{*}$ \\
$\begin{array}{l}\text { * Reference given } \\
\text { ** Reference not given }\end{array}$ & & \\
T1D: type 1 diabetes & & & \\
\hline
\end{tabular}

treatment on the metabolic control of diabetic patients $(14,21)$. On the other hand, the number of studies on the relation of $25(\mathrm{OH}) \mathrm{D}$ levels with daily insulin requirement and metabolic control in children is limited. Johnson et al (22) found an inversely proportional correlation between fasting blood sugar level and $25(\mathrm{OH}) \mathrm{D}$ in pediatric outpatients.
Svoren et al (11) and Tunc et al (19) showed that low serum 25(OH)D levels were associated with poor metabolic control in T1D patients. In our study, we did not find a significant correlation between serum 25(OH)D levels and $\mathrm{HbA} 1 \mathrm{c}$ or duration of diabetes. Similarly, Janner et al (20) had reported that there was no relationship between $\mathrm{HbA} 1 \mathrm{c}$ levels and vitamin $\mathrm{D}$ status in T1D children and adolescents. The daily insulin requirements of our subjects also did not change with their vitamin D status.

In conclusion, although we could not show a significant association between vitamin D deficiency and metabolic parameters, the frequency of vitamin $D$ deficiency in T1D children can be substantial. Vitamin D status of these children should be assessed in terms of bone health. Even in the absence of signs of rickets, vitamin D supplementation must be suggested to vitamin $\mathrm{D}$ deficient T1D children.

\section{References}

1. Bikle D. Nonclassic actions of vitamin D. J Clin Endocrinol Metab 2009;94:26-34.

2. Gulseth $H L$, Gjelstad IM, Tierney $A C$, Lovegrove JA, Defoort C, Blak EE, Lopez-Miranda J, Kiec-Wilk B, Risérus U, Roche HM, Drevon CA, Birkeland KI. Serum vitamin $\mathrm{D}$ concentration does not predict insulin action or secretion in European subjects with the metabolic syndrome. Diabetes Care 2010:33;923-925. 
3. Chiu KC, Chu A, Go VL, Saad MF. Hypovitaminosis $\mathrm{D}$ is associated with insulin resistance and beta cell dysfunction. Am J Clin Nutr 2004;79:820-825.

4. Zhao G, Ford ES, Li C. Associations of serum concentrations of 25-hydroxyvitamin $D$ and parathyroid hormone with surrogate markers of insulin resistance among U.S. adults without physician-diagnosed diabetes: NHANES, 2003-2006. Diabetes Care 2010;33:344-347.

5. Kayaniyil $S$, Vieth $R$, Retnakaran $R$, Knight JA, Qi $Y$, Gerstein HC, Perkins BA, Harris SB, Zinman B, Hanley AJ. Association of vitamin $D$ with insulin resistance and beta-cell dysfunction in subjects at risk for type 2 diabetes. Diabetes Care 2010;33:1379-1381

6. Reis JP, von Mühlen D, Miller ER 3rd, Michos ED, Appel LJ. Vitamin D status and cardiometabolic risk factors in the United States adolescent population. Pediatrics 2009:124:371-379.

7. Delvin EE, Lambert M, Levy E, O'Loughlin J, Mark S, Gray-Donald K, Paradis G. Vitamin D status is modestly associated with glycemia and indicators of lipid metabolism in French-Canadian children and adolescents. J Nutr 2010;140:987-991.

8. Pozzilli $P$, Manfrini $S$, Crino A, Picardi A, Leomanni $C$, Cherubini $V$, Valente $L$, Khazrai $M$, Visalli $N$; IMDIAB group. Low levels of 25-hydroxyvitamin D3 and 1,25dihydroxyvitamin D3 in patients with newly diagnosed type 1 diabetes. Horm Metab Res 2005;37:680-683.

9. Littorin B, Blom P, Scholin A, Arnqvist HJ, Blohme G, Bolinder J, Ekbom-Schnell A, Eriksson JW' Gudbjörnsdottir S, Nyström L, Ostman J, Sundkvist G. Lower levels of plasma 25-hydroxyvitamin D among young adults at diagnosis of autoimmune T1D compared with control subjects: results from the nationwide Diabetes Incidence Study in Sweden (DISS). Diabetologia 2006;49:2847-2852.

10. Greer RM, Rogers MA, Bowling FG, Buntain HM, Harris M, Leong GM, Cotterill AM. Australian children and adolescents with T1D have low vitamin D levels. Med $J$ Aust 2007:187:59-60.

11. Svoren BM, Volkening LK, Wood JR, Laffel LM. Significant vitamin $\mathrm{D}$ deficiency in youth with T1D mellitus. J Pediatr 2009;154:132-134.
12. Borkar VV, Devidayal, Verma S, Bhalla AK. Low levels of vitamin D in North Indian children with newly diagnosed type 1 diabetes. Pediatr Diabetes 2010;11:345-350.

13. Bener A, Alsaied A, Al-Ali M, Al-Kubaisi A, Basha B, Abraham A, Guiter G, Mian M. High prevalence of vitamin $\mathrm{D}$ deficiency in T1D mellitus and healthy children. Acta Diabetol 2009;46:183-189.

14. Aljabri KS, Bokhari SA, Khan MJ. Glycemic changes after vitamin $D$ supplementation in patients with type 1 diabetes mellitus and vitamin D deficiency. Ann Saudi Med 2010;30:454-458

15. Hatun S, Islam O, Cizmecioglu F, Kara B, Babaoglu K, Berk F, Gokalp AS. Subclinical vitamin d deficiency is increased in adolescent girls who wear concealing clothing. J Nutr 2005:135:218-222.

16. Misra M, Pacaud D, Petryk A, Collett-Solberg PF, Kappy M; Drug and Therapeutics Committee of the Lawson Wilkins Pediatric Endocrine Society. Vitamin D deficiency in children and its management: review of current knowledge and recommendations. Pediatrics 2008:122:398-417.

17. Hyppönen $E$, Läärä $E$, Reunanen $A$, Järvelin $M R$, Virtanen SM. Intake of vitamin $D$ and risk of type 1 diabetes: a birth-cohort study. Lancet 2001;358:1500-1503.

18. Stene LC, Joner G. Use of cod liver oil during the first year of life is associated with lower risk of childhood onset type 1 diabetes: a large population-based, case control study. Am J Clin Nutr 2003;78:1128-1134.

19. Tunc $\mathrm{O}$, Cetinkaya $\mathrm{S}$, Kizilgun $\mathrm{M}$ et al. Evaluation of the relation between vitamin $D$ and insulin requirements and frequency of osteopenia/osteoporosis in childhood with type 1 diabetes. 49th Annual Meeting of the ESPE September 22-25,2010.

20. Janner $M$, Ballinari $P$, Mullis EP, Flück $C E$. High prevalance of vitamin D deficiency in children and adolescents with type 1 diabetes. Swiss Med Wkly 2010;140:13091.

21. Walter M, Kaupper T, Adler K, Foersch J, Bonifacio E, Ziegler AG. No effect of the 1 alpha,25-dihydroxyvitamin D3 on beta-cell residual function and insulin requirement in adults with new-onset type 1 diabetes. Diabetes Care 2010;33:1443-1448

22. Johnson MD, Nader NS, Weaver AL, Singh $R$, Kumar $S$. Relationships between 25-hydroxyvitamin $D$ levels and plasma glucose and lipid levels in pediatric outpatients. J Pediatr 2010;156:444-449. 